\title{
PENGARUH PENERAPAN METODE PEMBELAJARAN PERMAINAN KREATIF DENGAN MEDIA HANGER PLAY TERHADAP KEAKTIFAN DAN HASIL BELAJAR SISWA KELAS VII SMP NEGERI 11 SURABAYA
}

\author{
Noor Riyadi Hidayat* ${ }^{1}$, Shoffan Shoffa ${ }^{2}$, Himmatul Mursyidah ${ }^{3}$, Iis Holisin ${ }^{4}$ \\ $1,2,3,4$ Universitas Muhammadiyah Surabaya \\ riyady01hidayat@gmail.com*1, shoffan.pendmat@fkip.um-surabaya.ac.id ${ }^{2}$, \\ himmatul.pendmat@fkip.um-surabaya.ac.id ${ }^{3}$, iisholisin.pendmat@fkip.um- \\ surabaya.ac.id ${ }^{4}$ \\ *Corresponding author
}

Received 12 June 2021; revised 01 July 2021; accepted 07 July 2021.

\begin{abstract}
ABSTRAK
Belajar merupakan kegiatan penting bagi setiap orang. Sebuah survey memperlihatkan bahwa $82 \%$ anak-anak yang masuk sekolah pada usia 5-6 tahun memiliki citra diri positif tentang kemampuan belajar mereka sendiri. Namun angka tersebut turun drastis menjadi hanya 18\% ketika usia mereka beranjak 16 tahun. Penyebab menurunnya kemampuan belajar ini adalah sikap malas, menggampangkan tugas, dan cara belajar siswa di rumah yang terlalu santai. Sama halnya ketika siswa belajar matematika. Diketahui konsep matematika pada umumnya bersifat abstrak sehingga sulit bagi siswa untuk dapat memahami materi dengan hanya mendengarkan penjelasan guru. Berdasarkan survey tersebut, digunakan pembelajaran permainan kreatif dengan menggunakan media Hanger Play sebagai alat bantu untuk menjadikan pembelajaran matematika lebih menarik. Tujuan penelitian ini untuk mengetahui ada tidaknya pengaruh metode permainan kreatif dengan media Hanger Play terhadap keaktifan dan hasil belajar siswa kelas VII SMP Negeri 11 Surabaya. Metode yang digunakan dalam penelitian ini adalah metode deskriptif kuantitatif. Karena penelitian ini berupaya mengetahui ada tidaknya pengaruh penerapan metode permainan kreatif dengan media Hanger Play terhadap keaktifan dan hasil belajar siswa. Kemudian di kembangkan secara deskriptif. Teknik pengumpulan data menggunakan observasi dan angket respon siswa. Hasil penelitian menunjukkan bahwa terdapat pengaruh positif penggunaan metode permainan kreatif dengan media Hanger Play terhadap keaktifan dan hasil belajar siswa yang. Selain itu, dari hasil observasi diperoleh tingkat signifikan yang tinggi (siswa tertarik) terhadap pembelajaran matematika menggunakan metode dan media tersebut.
\end{abstract}

Kata kunci: hanger play, hasil belajar, keaktifan, metode permainan kreatif, pengaruh. 


\begin{abstract}
Learning is an important activity for everyone. A survey shows that $82 \%$ of children who enter school at the age of 5-6 years have a positive self-image about their own learning abilities. However, that number dropped drastically to only $18 \%$ when they turned 16 years old. The causes of this decline in learning abilities are lazy attitudes, simplify tasks, and the way students study at home is too relaxed. The same is true when students study mathematics. It is known that mathematical concepts are generally abstract so it is difficult for students to be able to understand the material by just listening to the teacher's explanation. Based on the survey, creative game learning was used using Hanger Play media as a tool to make mathematics learning more interesting. The purpose of this study was to determine whether there was an effect of the creative game method with Hanger Play media on the activity and learning outcomes of seventh grade students of SMP Negeri 11 Surabaya. The method used in this research is descriptive quantitative method. Because this study seeks to determine whether there is an effect of applying the creative game method with Hanger Play media on student activity and learning outcomes. Then developed descriptively. Data collection techniques using observation and student response questionnaires. The results showed that there was a positive effect of using the creative game method with Hanger Play media on the activeness and learning outcomes of students. In addition, from the results of observations obtained a high significant level (students are interested) in learning mathematics using these methods and media.
\end{abstract}

Keywords: hanger play, learning outcomes, activeness, creative game methods, influence.

\title{
PENDAHULUAN
}

Belajar merupakan kegiatan penting bagi setiap orang. Sebuah survey memperlihatkan bahwa 82\% anak-anak yang masuk sekolah pada usia 5-6 tahun memiliki citra diri positif tentang kemampuan belajar mereka sendiri. Namun angka tersebut turun drastis menjadi hanya 18\% ketika usia mereka beranjak 16 tahun (Suhardi, 2015). Penyebab menurunnya tingkat belajar ini diakibatkan 2 faktor, yaitu faktor internal dan faktor eksternal. Faktor internal yang berpengaruh dalam belajar siswa yaitu sikap malas, lalai waktu, menggampangkan tugas, dan cara belajar siswa di rumah yang terlalu santai. Sedangkan faktor eksternal yang berpengaruh dalam belajar siswa adalah faktor dari keluarga seperti masalah dari keluarga yang mempengaruhi belajar, serta faktor sekolah yang dipengaruhi guru dan teman. Perlu diingat, guru tidak hanya sekedar memberi ilmu tetapi juga 
secara tidak langsung membentuk karakter siswa (Juniarti, Bahari, \& Riva'ie, 2015).

Menurut Badan Standar Nasional Pendidikan, pembelajaran matematika di SMP bertujuan agar siswa memiliki kemampuan sebagai berikut: (1) memahami konsep matematika, (2) menggunakan penalaran, (3) memecahkan masalah, (4) mengkomunikasikan gagasan, (5) memiliki sikap menghargai matematika, yatu rasa ingin tahu perhatian, dan minat dalam mempelajari matematika (BNSP, 2006). Dengan demikian, guru harus merancang pembelajaran agar siswa dapat memiliki lima kemampuan tersebut dengan cara menetapkan tujuan pembelajaran yang akan dicapai.

Dari sekian banyak mata pelajaran yang ada di jenjang Sekolah Menengah Pertama (SMP), menurut hasil wawancara dengan guru SMP Negeri 11 Surabaya diperoleh bahwa matematika merupakan salah satu mata pelajaran yang dianggap sulit. Sering kali muncul keluhan dari siswa bahwa matematika adalah pelajaran yang menjenuhkan dan bahkan dianggap menakutkan bagi siswa. Bukan hanya itu saja, masih banyak perlakuan siswa yang menganggap remeh mata pelajaran matematika, seperti siswa sering tidak membawa buku paket dengan alasan lupa. Ada juga yang tertidur pulas saat jam pelajaran matematika. Bahkan siswa berani untuk mengatakan kepada guru bahwa jam pelajaran matematika lebih baik kosong. Hal-hal tersebut dapat berdampak pada rendahnya keaktifan dan hasil belajar matematika.

Penyebab dari masalah yang ditemui di SMP Negeri 11 Surabaya diantaranya guru lebih banyak menggunakan metode ceramah dengan alat bantu pembelajaran hanya berupa papan tulis dan LCD, belum ada media khusus yang dibuat dan digunakan dalam pembelajaran matematika. Keterbatasan metode dan media yang digunakan guru dapat berakibat siswa kurang aktif dalam mengikuti pembelajaran dan berdampak pada hasil belajar siswa di bawah rata-rata atau nilai di bawah standar Kriteria Ketuntasan Minimal (KKM) yang telah ditentukan oleh sekolah (Aunurrahman, 2009; Biantoro, Kristanti, \& Mursyidah, 2020), hal tersebut juga dialami siswa di SMP Negeri 11 Surabaya.

Berdasarkan permasalahan yang ada, diperlukan metode pembelajaran yang menarik bagi siswa untuk meningkatkan keaktifan dan hasil belajar pada 
mata pelajaran matematika di SMP Negeri 11 Surabaya. Salah satu metode yang dapat diterapkan untuk mengatasi masalah tersebut adalah Metode Permainan Kreatif (Antara, 2018; Handini, 2014; Lestari, 2015; Rahmawanti, 2016). Metode ini dapat mengembangkan berbagai aspek perkembangan pada diri anak. Perkembangan pada anak selain aspek fisik atau motorik juga terdapat aspek kognitif, bahasa, sosial, dan emosional (Nugraha, 2015). Oleh karena itu, dilakukan penelitian untuk mengetahui pengaruh penerapan metode pembelajaran Permainan Kreatif dengan dilengkapi media Hanger Play terhadap keaktifan dan hasil belajar siswa kelas VII SMP Negeri 11 Surabaya. Hanger Play merupakan media yang berbahan dasar utama penjepit kertas. Media ini melatih siswa untuk belajar matematika melalui kerjasama kelompok, membuat pembelajaran lebih menarik, dan dapat meningkatkan konsentrasi siswa dalam belajar.

\section{METODE PENELITIAN}

Penelitian ini menggunakan penelitian kuantitatif, yaitu penelitian yang pada dasarnya menggunakan pendekatan deduktif-induktif. Pendekatan ini berangkat dari suatu kerangka teori, gagasan para ahli, maupun pemahaman peneliti berdasarkan pengalamannya, kemudian dikembangkan menjadi permasalahan-permasalahan beserta pemecahannya yang digunakan untuk memperoleh pembenaran (verifikasi) atau penolakan dalam bentuk dukungan data empiris di lapangan. Dengan kata lain dalam penelitian kuantitatif peneliti berangkat dari paradigma teoritik menuju data, dan berakhir pada penerimaan atau penolakan terhadap teori yang digunakan (Sugiono, 2016).

Desain yang digunakan dalam penelitian ini adalah true eksperimental design. Dalam design ini, peneliti dapat mengontrol semua variabel yang dapat mempengaruhi jalannya ekperimen. Salah satu bentuk dari true eksperimental design yaitu one group pretest posttest design. Desain yang dilakukan yakni dengan membandingkan hasil perolehan skor dari pelaksanaan pretest $\left(O_{1}\right)$ dan posttest $\left(\mathrm{O}_{2}\right)$ seperti pada Gambar 1 .

$\begin{array}{ccc}\text { Pretest } & \text { Treatment } & \text { Posttest } \\ O_{1} & X & O_{2}\end{array}$

Gambar 1. Desain One Group Pretest Posttest 
Penelitian ini dilaksanakan pada tanggal 19 Juli sampai dengan 19 Agustus 2019 dengan populasi siswa kelas VII SMP Negeri 11 Surabaya tahun ajaran 2019/2020 yang terdiri dari 6 kelas, yaitu VII-A, VII-B, VII-C, VII-D, VII-E, dan VII-F. Tidak terdapat adanya penggolongan kelas antara siswa yang berkemampuan tinggi, sedang, dan rendah. Setiap kelas terdiri dari siswa yang heterogen karena pada masing-masing kelas ada yang mempunyai kemampuan belajar yang tinggi, sedang, dan rendah. Adapun kelas yang diambil sebagai sampel dalam penelitian ini adalah kelas VII-A yang terdiri dari 32 siswa. Penentuan sampel dilakukan berdasarkan hasil observasi dan wawancara dengan guru matematika. Menurut guru matematika SMP Negeri 11 Surabaya siswa kelas VII-A kurang aktif dalam mengikuti proses pembelajaran. Selain itu, hasil belajar siswa dilihat dari nilai rata-rata kelas tergolong rendah.

Data yang dihimpun dalam penelitian ini meliputi data keaktifan siswa dari hasil observasi, data keterlaksanaan pembelajaran oleh guru dari hasil observasi, data hasil belajar siswa dari nilai pretest dan posttets, serta data respon siswa setelah mengikuti pembelajaran matematika menggunakan Metode Permainan Kreatif dengan media Hanger Play yang diperoleh dari kuesioner. Untuk kriteria keaktifan siswa yang digunakan dalam penelitian ini diberikan pada Tabel 1.

Tabel 1. Kriteria Keaktifan Siswa

\begin{tabular}{|c|c|c|c|}
\hline No & $\begin{array}{c}\text { Kategori Aktivitas Siswa yang } \\
\text { Diamati }\end{array}$ & $\begin{array}{l}\text { Waktu } \\
\text { Ideal } \\
\text { (Menit) }\end{array}$ & $\begin{array}{c}\text { Rentang Waktu dengan } \\
\text { Toleransi } 10 \\
\text { (Menit) }\end{array}$ \\
\hline 1 & $\begin{array}{l}\text { Mendengar/memperhatikan penjelasan } \\
\text { guru/siswa }\end{array}$ & 15 & $11,88 \leq x \leq 18,13$ \\
\hline 2 & $\begin{array}{l}\text { Menemukan jawaban dan cara } \\
\text { menjawab masalah }\end{array}$ & 18 & $15,75 \leq x \leq 20,25$ \\
\hline 3 & Membaca buku paket & 8 & $7 \leq x \leq 9$ \\
\hline 4 & Berdiskusi antar teman & 20 & $17,50 \leq x \leq 22,50$ \\
\hline 5 & Bertanya kepada guru jika kesulitan & 3 & $2,63 \leq x \leq 4,38$ \\
\hline 6 & $\begin{array}{l}\text { Mempresentasikan hasil diskusi } \\
\text { kelompok }\end{array}$ & 4 & $3,50 \leq x \leq 4,50$ \\
\hline 7 & Mengajukan pertanyaan/menanggapi & 1 & $0,75 \leq \times \leq 1,25$ \\
\hline
\end{tabular}




\begin{tabular}{|c|c|c|c|}
\hline No & $\begin{array}{c}\text { Kategori Aktivitas Siswa yang } \\
\text { Diamati }\end{array}$ & $\begin{array}{l}\text { Waktu } \\
\text { Ideal } \\
\text { (Menit) }\end{array}$ & $\begin{array}{c}\text { Rentang Waktu dengan } \\
\text { Toleransi } 10 \\
\text { (Menit) }\end{array}$ \\
\hline & pada saat presentasi kelompok & & \\
\hline 8 & Perilaku yang tidak relevan & 0 & 0 \\
\hline
\end{tabular}

Siswa dikatakan aktif apabila keseluruhan jumlah kategori yang efektif (memenuhi waktu ideal) lebih dari 50\%. Sedangkan kriteria keterlaksanaan pembelajaran $(k p)$ oleh guru diberikan pada Tabel 2.

Tabel 2. Kriteria Keterlaksanaan Pembelajaran

\begin{tabular}{cc}
\hline Kriteria Penilaian & Persentase \\
\hline Sangat Baik & $k p>80 \%$ \\
Baik & $75 \%<k p \leq 80 \%$ \\
Kurang Baik & $65 \%<k p \leq 70 \%$ \\
Tidak Baik & $k p \leq 60 \%$ \\
\hline
\end{tabular}

Untuk data respon siswa, dianalisis menggunakan persentase. Respon siswa dikatakan positif jika presentase kriteria positif dan sangat positif mencapai $70 \%$ atau lebih. Kriteria respon siswa $(R)$ disajikan dalam Tabel 3.

Tabel 3. Kriteria Respon Siswa

\begin{tabular}{cc}
\hline Kategori & Persentase \\
\hline Sangat Positif & $80 \% \leq R<100 \%$ \\
Positif & $60 \% \leq R<80 \%$ \\
Cukup Positif & $40 \% \leq R<60 \%$ \\
Kurang Positif & $20 \% \leq R<40 \%$ \\
Tidak Positif & $0 \% \leq R<20 \%$ \\
\hline
\end{tabular}

Sumber: (Ula, Kristanti, \& Mursyidah, 2019)

Batas pencapaian ketuntasan belajar di SMP Negeri 11 Surabaya ditetapkan pada skor 78. Pembelajaran di kelas dikatakan tuntas apabila persentase siswa dalam 
satu kelas yang hasil belajarnya mencapai batas pencapaian ketuntasan belajar setelah menerapkan metode permainan kreatif menggunakan media hanger play lebih dari 75\%. Kriteria hasil belajar diberikan pada Tabel 4.

Tabel 4. Kriteria Hasil Belajar

\begin{tabular}{cc}
\hline Kriteria Penilaian & Persentase \\
\hline Sangat baik & $x>80 \%$ \\
Baik & $75 \%<x \leq 80 \%$ \\
Kurang baik & $65 \%<x \leq 70$ \\
Sangat kurang baik & $x \leq 60 \%$ \\
\hline
\end{tabular}

Sumber: (Wuri, 2017)

Adapun untuk uji hipotesis, dilakukan menggunakan bantuan software SPSS yang meliputi uji normalitas dan uji perbedaan dua rata-rata (uji-t). Hipotesis dalam penelitian ini diberikan sebagai berikut:

$H_{0}=$ hasil pembelajaran sebelum menggunakan metode Permainan Kreatif dengan media Hanger Play sama dengan hasil pembelajaran setelah menggunakan metode Permainan Kreatif dengan media Hanger Play

$H_{1}=$ hasil pembelajaran sebelum menggunakan metode Permainan Kreatif dengan media Hanger Play berbeda dengan hasil pembelajaran setelah menggunakan metode Permainan Kreatif dengan media Hanger Play.

\section{HASIL PENELITIAN DAN PEMBAHASAN}

Sebelum dilakukan pengambilan data, enam buah instrumen penelitian yaitu RPP, LKS, lembar observasi keaktifan siswa, lembar observasi keterlaksanaan pembelajaran, pretest dan posttest, serta angket respon siswa terlebih dahulu divalidasi oleh guru matematika dan dosen pendidikan matematika. Melalui masukan dari para ahli, instrumen penelitian layak untuk digunakan dalam pengambilan data.

Penelitian dilakukan dalam 2 kali pertemuan pada materi himpunan. Data yang telah terhimpun selanjutnya dilakukan analisis. Untuk keaktifan siswa kelas VII-A dengan berpedoman pada Tabel 1 diberikan hasil seperti pada Tabel 5. Terdapat 3 jenis aktivitas siswa yang termasuk dalam kategori tidak efektif, yaitu 
menemukan jawaban dan cara menjawab masalah, diskusi dengan teman, serta mempresentasikan hasil diskusi. Untuk aktivitas menemukan jawaban dan diskusi, rata-rata waktu yang digunakan lebih singkat dari rentang waktu toleransi. Hal tersebut terjadi karena belum semua siswa yang tergabung dalam kelompok berpartisipasi aktif dan masih ada yang sibuk sendiri seperti diberikan pada Gambar 1.

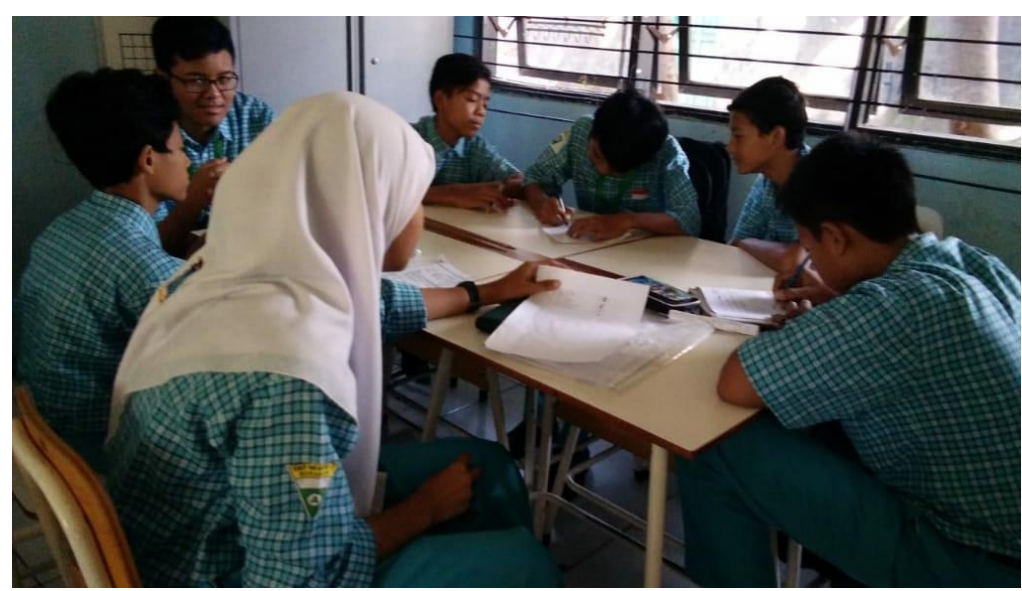

Gambar 1. Suasana Diskusi dalam Kelompok

Sedangkan rata-rata waktu untuk mempresentasikan hasil melebihi rentang waktu toleransi, artinya dibutuhkan waktu yang lebih lama saat siswa menjelaskan hasil diskusi kelompoknya di depan kelas seperti Gambar 2. Hal ini terjadi karena siswa belum terbiasa untuk melakukan aktivitas presentasi di depan kelas, serta belum semua siswa terlibat aktif saat diskusi kelompok. Namun demikian, apabila ini dibiasakan maka tidak menutup kemungkinan siswa akan menjadi terbiasa sehingga menjadi lebih efektif.

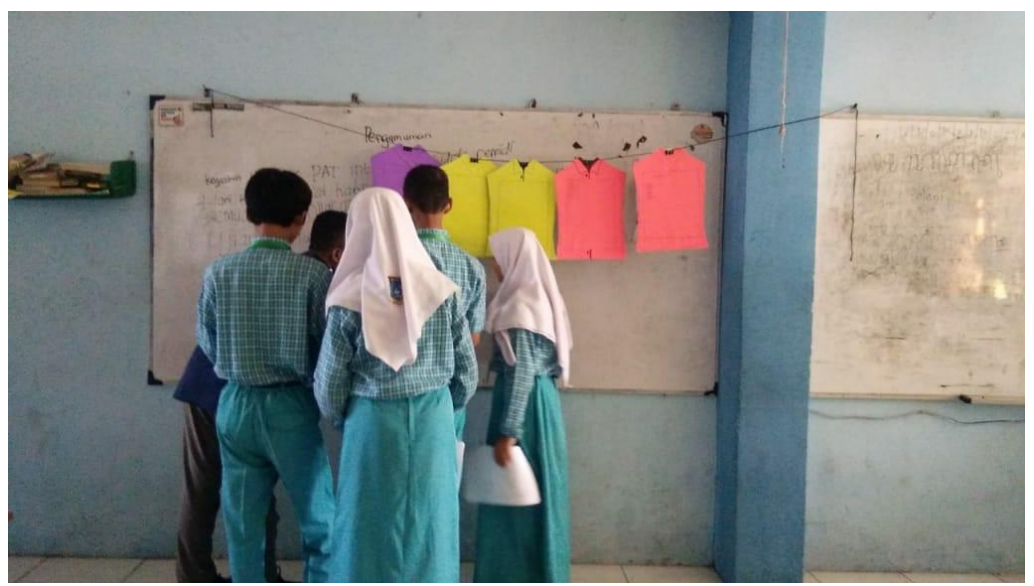

Gambar 1. Siswa Mempresentasikan Hasil Diskusi Kelompok 
Meskipun masih terdapat 3 aktivitas siswa yang tidak efektif, diperoleh rata-rata keaktifan siswa adalah $62,5 \%$ sehingga dapat dikatakan keaktifan siswa saat mengikuti proses pembelajaran matematika menggunakan metode Permainan Kreatif dengan media Hanger Play termasuk dalam kategori efektif.

Tabel 5. Keaktifan Siswa saat Pembelajaran Matematika Menggunakan Metode Permainan Kreatif dengan Media Hanger Play

\begin{tabular}{|c|c|c|c|c|}
\hline No & $\begin{array}{c}\text { Aktivitas siswa yang } \\
\text { diamati }\end{array}$ & $\begin{array}{c}\text { Rata-rata } \\
\text { waktu yang } \\
\text { digunakan } \\
\text { (menit) }\end{array}$ & $\begin{array}{c}\text { Rentang waktu } \\
\text { dengan toleransi } 10 \\
\text { (menit) }\end{array}$ & Kategori \\
\hline 1 & $\begin{array}{l}\text { Mendengar/memper- } \\
\text { hatikan penjelasan } \\
\text { guru/siswa }\end{array}$ & 15 & $11,88 \leq x \leq 18,13$ & Efektif \\
\hline 2 & $\begin{array}{l}\text { Menemukan jawaban } \\
\text { dan cara menjawab } \\
\text { masalah }\end{array}$ & 3 & $15,75 \leq x \leq 20,25$ & $\begin{array}{c}\text { Tidak } \\
\text { Efektif }\end{array}$ \\
\hline 3 & Membaca buku paket & 7 & $7 \leq x \leq 9$ & Efektif \\
\hline 4 & $\begin{array}{l}\text { Berdiskusi antar } \\
\text { teman }\end{array}$ & 4 & $17,50 \leq x \leq 22,50$ & $\begin{array}{l}\text { Tidak } \\
\text { Efektif }\end{array}$ \\
\hline 5 & $\begin{array}{l}\text { Bertanya kepada guru } \\
\text { jika kesulitan }\end{array}$ & 4 & $2,63 \leq x \leq 4,38$ & Efektif \\
\hline 6 & $\begin{array}{l}\text { Mempresentasikan } \\
\text { hasil diskusi } \\
\text { kelompok }\end{array}$ & 6 & $3,50 \leq x \leq 4,50$ & $\begin{array}{c}\text { Tidak } \\
\text { Efektif }\end{array}$ \\
\hline 7 & $\begin{array}{l}\text { Mengajukan } \\
\text { pertanyaan/menang- } \\
\text { gapi pada saat }\end{array}$ & 1 & $0,75 \leq \times \leq 1,25$ & Efektif \\
\hline 8 & $\begin{array}{l}\text { presentasi kelompok } \\
\text { Perilaku yang tidak } \\
\text { relevan }\end{array}$ & 0 & 0 & Efektif \\
\hline
\end{tabular}


Hal ini sejalan dengan penelitian terdahulu tentang penerapan metode bermain kreatif dalam pembelajaran matematika kelas III MI yang diperoleh hasil bahwa metode permainan kreatif berpengaruh dalam keatifan siswa, bahkan dapat meningkatkan keaktifan siswa (Rahmawanti, 2016).

Selain keaktifan siswa, kemampuan guru dalam mengelola pembelajaran juga diobservasi untuk mendapatkan data terkait keterlaksanaan pembelajaran matematika menggunakan metode Permainan Kreatif dengan media Hanger Play. Terdapat 24 kegiatan yang diamati dalam pengelolaan pembelajaran oleh guru yang dibagi menjadi 6 fase. Pada fase I, terdapat 4 kegiatan yang diamati yaitu (1) guru membuka pelajaran dan meminta salah satu siswa untuk memimpin doa, (2) guru memotivasi dan mengingatkan kembali materi yang telah disampaikan sebelumnya, (3) guru menyampaikan tujuan pembelajaran yang ingin di capai, (4) guru memberikan gambaran tentang pentingnya memahami konsep materi himpunan dan memberikan gambaran tentang aplikasi nilai sehari-hari. Pada fase II, terdapat 6 kegiatan yang diamati yaitu (5) guru mempersiapkan media Hanger Play, (6) guru menyampaikan teknis bermain dengan media Hanger Play, (7) guru menyampaikan materi himpunan, (8) guru memberikan pertanyaan kepada siswa sebagai stimulus, (9) guru memberikan penjelasan terkait dengan materi dari hasil respon siswa setelah diberikan stimulus, dan (10) guru memberikan kesempatan kepada siswa untuk bertanya. Pada fase III, terdapat 4 kegiatan yang diamati yaitu (11) guru mengorganisir siswa ke dalam kelompok heterogen yang terdiri 5-6 anggota, (12) guru membagikan LKS, (13) guru memberikan penjelasan cara mengerjakan LKS, dan (14) guru mengorganisir siswa untuk belajar sambil bermain dengan media Hanger Play di kelas.

Pada fase IV, terdapat 6 kegiatan yang diamati yaitu (15) setiap kelompok mengambil jenis data sesuai dengan petunjuk yang disampaikan oleh guru atau yang tertulis dalam LKS, (16) setiap kelompok menulis jenis data yang diambil kemudian ditulis di LKS, (17) setiap kelompok menuliskan jenis data yang diperoleh kedalam media Hanger Play sesuai dengan jenis data masing-masing, (18) setiap kelompok memilih jenis data yang ada di media Hanger Play kemudian mengolah data tersebut lalu ditulis dalam LKS, (19) setelah data di olah setiap kelompok, hasil data tersebut ditulis pada media Hanger Play, dan (20) 
setiap kelompok mempresentasikan hasil secara bergantian. Pada fase V, terdapat 2 kegiatan yang diamati yaitu (21) setiap kelompok memberikan kesimpulan dari permainan dengan media Hanger Play, dan (22) guru memberikan kesimpulan terakhir sebelum menutup pembelajaran. Terakhir pada fase VI, terdapat 2 kegiatan yang diamati yaitu (23) guru mengumumkan dan memberikan apresiasi kepada kelompok terbaik, dan (24) guru mengucapkan salam penutup.

Berdasarkan hasil pengamatan diperoleh rata-rata keterlaksanaan pembelajaran untuk 24 kegiatan yang telah diamati pada pertemuan 1 dan 2 berturut-turut adalah 82,29\% dan 89,58\%. Berdasarkan Tabel 2, hasil tersebut menunjukkan bahwa keterlaksanaan pembelajaran matematika di kelas VII-A SMP Negeri 11 Surabaya menggunakan metode Permainan Kreatif dengan media Hanger Play termasuk dalam kategori sangat baik.

Data berikutnya yang diperoleh adalah respon siswa setelah mengikuti pembelajaran matematika menggunakan metode Permainan Kreatif dengan media Hanger Play. Data ini dihimpun dengan menggunakan angket yang berisi 6 pertanyaan. Hasil angket respon siswa kemudian dianalisa berdasarkan Tabel 3 sehingga diperoleh hasil seperti pada Tabel 6.

Tabel 6. Data Respon Siswa setelah Mengikuti Pembelajaran Matematika

Menggunakan Metode Permainan Kreatif dengan Media Hanger Play

\begin{tabular}{|c|c|c|c|c|c|}
\hline \multirow{2}{*}{ No } & \multirow{2}{*}{ Pernyataan } & \multicolumn{2}{|c|}{ Hasil Angket } & \multirow{2}{*}{$\begin{array}{c}\text { Persentase } \\
\text { Hasil } \\
\text { Angket }\end{array}$} & \multirow{2}{*}{ Kategori } \\
\hline & & ya & tidak & & \\
\hline 1 & $\begin{array}{l}\text { Pembelajaran } \\
\text { menggunakan metode } \\
\text { permainan kreatif } \\
\text { membuat saya senang dan } \\
\text { tertarik terhadap mata } \\
\text { pelajaran matematika }\end{array}$ & 32 & 0 & $100 \%$ & Sangat Positif \\
\hline 2 & $\begin{array}{l}\text { Pembelajaran } \\
\text { menggunakan metode } \\
\text { permainan kreatif } \\
\text { membuat saya mudah }\end{array}$ & 31 & 1 & $96 \%$ & Sangat Positif \\
\hline
\end{tabular}




\begin{tabular}{|c|c|c|c|c|c|}
\hline \multirow{2}{*}{ No } & \multirow{2}{*}{ Pernyataan } & \multicolumn{2}{|c|}{ Hasil Angket } & \multirow{2}{*}{$\begin{array}{c}\text { Persentase } \\
\text { Hasil } \\
\text { Angket }\end{array}$} & \multirow{2}{*}{ Kategori } \\
\hline & & ya & tidak & & \\
\hline & $\begin{array}{l}\text { memahami mata pelajaran } \\
\text { matematika }\end{array}$ & & & & \\
\hline 3 & $\begin{array}{l}\text { Pembelajaran } \\
\text { menggunakan permainan } \\
\text { kreatif membuat saya aktif } \\
\text { dalam bekerja kelompok }\end{array}$ & 30 & 2 & $93 \%$ & Sangat Positif \\
\hline 4 & $\begin{array}{l}\text { Pembelajaran } \\
\text { menggunakan permainan } \\
\text { kreatif membuat saya } \\
\text { memiliki kemampuan } \\
\text { bekerjasama dengan baik }\end{array}$ & 31 & 1 & $96 \%$ & Sangat Positif \\
\hline 5 & $\begin{array}{l}\text { Pembelajaran } \\
\text { menggunakan permainan } \\
\text { kreatif seperti tidak ada } \\
\text { bedanya dengan pelajaran } \\
\text { yang biasa dilakukan }\end{array}$ & 7 & 25 & $78 \%$ & Positif \\
\hline 6 & $\begin{array}{l}\text { Pembelajaran } \\
\text { menggunakan permainan } \\
\text { kreatif membuat saya rajin } \\
\text { untuk menyimak materi } \\
\text { yang dipelajari. }\end{array}$ & 29 & 3 & $90 \%$ & Sangat Positif \\
\hline
\end{tabular}

Lebih lanjut, hasil analisa menunjukkan bahwa rata-rata persentase respon siswa setelah mengikuti pembelajaran matematika menggunakan metode Permainan Kreatif dengan media Hanger Play sebesar 92,17\%. Hal tersebut berarti respon siswa positif terhadap pembelajaran matematika menggunakan metode Permainan Kreatif dengan media Hanger Play. Ini sejalan dengan penelitian tentang pengaruh pembelajaran matematika metode permainan terhadap motivasi belajar siswa. Hasil penelitian menunjukkan metode permainan berpengaruh dan dapat 
meningkatkan motivasi belajar matematika siswa yang ditunjukkan melalui respon positif siswa (Handini, 2014; Lestari, 2015).

Adapun data hasil belajar siswa, diperoleh dari nilai pretest dan posttest. Nilai pretest digunakan untuk mengetahui sejauh mana kemampuan siswa dalam memahami materi himpunan sebelum diberikan perlakuan berupa pembelajaran matematika menggunakan metode Permainan Kreatif dengan media Hanger Play. Sedangkan nilai posttest untuk mengetahui kemampuan siswa memahami materi himpunan sesudah diberikan perlakuan. Berdasarkan hasil kerja siswa didapatkan nilai pretest dan posttest seperti pada Tabel 7.

Tabel 7. Data Hasil Belajar Siswa Kelas VII-A SMP Negeri 11 Surabaya

\begin{tabular}{llcccccc}
\hline \multirow{2}{*}{ No. } & \multicolumn{1}{c}{ Siswa } & Pretest & Posttest & No. & Siswa & Pretest & Posttest \\
\hline 1 & Abdul Aziz & 65 & 80 & 17 & Dean Elisa & 60 & 85 \\
2 & Berliana P. Siwa & 55 & 90 & 18 & Mayla A. & 50 & 90 \\
3 & Giffauzan A. & 45 & 85 & 19 & Muhammad & 55 & 80 \\
4 & Moch. Fikri & 50 & 95 & 20 & Riski A. P. & 55 & 80 \\
5 & Nizar Husain & 45 & 80 & 21 & Arjuna J. & 55 & 80 \\
6 & Abiyyu Bilhuda & 55 & 90 & 22 & Safira Hijri & 50 & 90 \\
7 & Brian Aditya & 55 & 80 & 23 & Dimas S. & 60 & 90 \\
8 & Gusti Candra & 55 & 90 & 24 & Moch D. S. & 60 & 80 \\
9 & Fariel F. & 45 & 80 & 25 & Putri Rita S & 55 & 85 \\
10 & Nabila Putri Ayu & 60 & 85 & 26 & Bening M. & 55 & 85 \\
11 & Aditia Hermanto & 55 & 80 & 27 & Sandy F. & 65 & 85 \\
12 & Caya Puspitasari & 50 & 90 & 28 & Hanif J. & 65 & 85 \\
13 & M. Fajar Hidayat & 55 & 80 & 29 & Nurul I. & 65 & 85 \\
14 & Fadhilla R. & 60 & 90 & 30 & Zakiya I. & 60 & 80 \\
15 & Nur Afia R. & 65 & 90 & 31 & Muflichul & 60 & 85 \\
16 & Amelia Y. S. & 55 & 85 & 32 & Chairul A. & 65 & 80 \\
\hline
\end{tabular}

Untuk keseluruhan nilai pretest didapatkan belum ada yang memenuhi kriteria ketuntasan dengan skor 78. Namun setelah dilakukan pembelajaran matematika menggunakan metode Permainan Kreatif dengan media Hanger Play didapatkan 
ketuntasan hasil belajar siswa menjadi $100 \%$. Hal ini sejalan dengan penelitianpenelitian terdahulu yang juga menunjukkan bahwa metode permainan kreatif dapat meningkatkan hasil belajar matematika siswa (Rahmawanti, 2016).

Selanjutnya, dari data hasil pretest dan posttest dilakukan analisa lebih lanjut untuk pengujian hipotesis ada tidaknya pengaruh pembelajaran matematika menggunakan metode Permainan Kreatif dengan media Hanger Play terhadap hasil belajar siswa. Dengan bantuan software SPSS berturut-turut dilakukan uji normalitas data dengan metode Kolmogorov-Smirnov, dan uji hipotesis menggunakan uji-t. Hasil olah data menggunakan SPSS dan interpretasi hasil diberikan pada Tabel 8.

Tabel 8. Hasil Uji Hipotesis

\begin{tabular}{llll}
\hline \multicolumn{1}{c}{$\begin{array}{c}\text { Hipotesis } \\
\text { Penelitian }\end{array}$} & Uji Normalitas & Uji-t & Interpretasi \\
\hline Pengaruh & Data signifikan & Data signifikan & Hipotesis diterima \\
penerapan metode & bernilai 0,884 & bernilai 0,000 & \\
permainan kreatif & & & \\
dengan media & & & \\
hanger play & & \\
terhadap hasil & & \\
belajar siswa & & \\
\hline
\end{tabular}

Berdasarkan Tabel 8 diketahui bahwa nilai signifikansi > 0,05 yang berarti data berdistribusi normal, sehingga dapat dilakukan uji-t. Untuk uji-t, didapatkan nilai signifikansi $<0,05$, maka $H_{0}$ ditolak dan $H_{1}$ diterima. Artinya, hasil pembelajaran sebelum menggunakan metode Permainan Kreatif dengan media Hanger Play berbeda dengan hasil pembelajaran setelah menggunakan metode Permainan Kreatif dengan media Hanger Play. Lebih lanjut, nilai signifikansi dalam uji-t < 0,05 berarti terdapat pengaruh signifikan antara satu variabel independen terhadap variabel dependen (Suwaibah, Holisin, \& Mursyidah, 2020), yaitu terdapat pengaruh pembelajaran matematika menggunakan metode Permainan Kreatif dengan media Hanger Play terhadap hasil belajar siswa kelas VII-A SMP Negeri 11 Surabaya yang bersifat positif. Hasil ini juga sejalan dengan penelitian 
terdahulu (Rahmawanti, 2016), metode permainan kreatif berpengaruh terhadap hasil belajar siswa meskipun media yang digunakan berbeda-beda.

\section{SIMPULAN}

Berdasarkan analisa hasil penelitian dapat disimpulkan bahwa pembelajaran matematika menggunakan metode Permainan Kreatif dengan media Hanger Play mempengaruhi keaktifan siswa kelas VII-A SMP Negeri 11 Surabaya selama proses pembelajaran. Meskipun masih terdapat 3 jenis aktivitas siswa yang tidak efektif, namun rata-rata keaktifan siswa menunjukkan nilai $62,5 \%$ yang berarti keaktifan siswa termasuk kategori efektif secara keseluruhan. Adapun dari hasil uji-t didapatkan bahwa pembelajaran matematika menggunakan metode Permainan Kreatif dengan media Hanger Play berpengaruh terhadap hasil belajar siswa kelas VII-A SMP Negeri 11 Surabaya yang bersifat positif.

\section{UCAPAN TERIMA KASIH}

Terimakasih disampaikan kepada kepala sekolah, guru matematika, dan siswa kelas VII SMP Negeri 11 Surabaya atas kesediaannya meluangkan waktu dan berpartisipasi dalam penelitian ini. Penulis juga mengucapkan terimakasih kepada dosen-dosen Program Studi Pendidikan Matematika, pimpinan Fakultas Keguruan dan Ilmu Pendidikan, serta pimpinan Universitas Muhammadiyah Surabaya yang telah memberikan dukungan dalam penelitian ini berupa masukan perbaikan dan perizinan.

\section{DAFTAR PUSTAKA}

Antara, P. A. (2018). Stimulasi metode permainan kreatif berdesain creative movement dan budi pekerti dalam mengembangkan kemampuan spasial anak. JPUD-Jurnal Pendidikan Usia Dini, 12(2), 301-310. https://doi.org/10.21009/JPUD.122.11

Aunurrahman. (2009). Belajar dan pembelajaran. Bandung: Alfabeta.

Biantoro, N. O. P. H., Kristanti, F., \& Mursyidah, H. (2020). Pengaruh penilaian kinerja dan kecerdasan emosional berdasarkan project based learning (PjBL) terhadap hasil belajar matematika siswa. Square: Journal of Mathematics and Mathematics Education, 2(2), 89-102. https://doi.org/10.21580/square.2020.2.2.5257

BNSP. (2006). Permendiknas RI no. 22 tahun 2006 tentang standar isi untuk satuan pendidikan dasar dan menengah. Jakarta: Kementerian Pendidikan 
Nasional.

Handini, A. (2014). Penerapan metode permainan untuk meningkatkan motivasi belajar matematika siswa (penelitian tindakan kelas di MI Jam'iyyatul Khair Ciputat). Jakarta: Universitas Islam Negeri Syarif Hidayatullah.

Juniarti, N., Bahari, Y., \& Riva'ie, W. (2015). Faktor penyebab menurunnya hasil belajar siswa pada pembelajaran sosiologi di SMA. Jurnal Pendidikan Dan Pembelajaran Khatulistiwa, 4(2), 1-11.

Lestari, I. N. (2015). Pengaruh metode permainan terhadap motivasi belajar matematika siswa kelas II SD N Plebengan. Yogyakarta: Universitas Negeri Yogyakarta.

Nugraha, B. (2015). Permainan kreatif untuk anak usia dini. Jurnal Pendidikan Anak, 2(1), 203-210. https://doi.org/10.21831/jpa.v2i1.3030

Rahmawanti, M. (2016). Penerapan metode bermain kreatif dalam pembelajaran matematika kelas III di MI Ma'arif NU 1 Pageraji Kecamatan Cilongok Kabupaten Banyumas. Purwokerto: Institut Agama Islam Negeri.

Sugiono. (2015). Metode Penelitian Pendidikan. Bandung: Alfabeta.

Sugiono. (2016). Metode Penelitian Kuantitatif, Kualitatif dan R\&D. Bandung: Alfabeta.

Suhardi, S. (2015). Efektivitas penerapan model pembelajaran deep learning cycle (DELC) dalam meningkatkan hasil belajar matematika kelas VII MTs. DDI Parangsialla Kab. Jeneponto. Makassar. Retrieved from http://repositori.uin-alauddin.ac.id/4341/

Suwaibah, D., Holisin, I., \& Mursyidah, H. (2020). Pengaruh Pendekatan Mathematical Habits of Mind terhadap Kemampuan Literasi Matematika. Jurnal Matematics Paedagogic, 4(2), 126-135.

Ula, M., Kristanti, F., \& Mursyidah, H. (2019). Efektivitas pembelajaran dicovery learning dengan media komik pada pembelajaran garis dan sudut di SMP negeri 7 Surabaya. JMPM: Jurnal Matematika Dan Pendidikan Matematika, 4(1), 17-28.

Wuri, R. F. (2017). Pengaruh penggunaan lembar kerja siswa (worksheet) berbasis kontruktivisme pada materi sifat-sifat bangun datar di kelas $V$-B SD Muhammadiyah 26 Surabaya. Surabaya: Universitas Muhammadiyah Surabaya. 